\title{
CONTRIBUTORS TO TEXT BOXES
}

\section{YVES BASSET}

Smithsonian Tropical Research

Institute, Panama

bassety@si.edu

STEPHANIE A. BOHLMAN

University of Florida

sbohlman@ufl.edu

\section{CATHERINE (CAT) CARDELÚS}

Colgate University

ccardelus@colgate.edu

\section{SAMANTHA K. CHAPMAN}

Villanova University

samantha.chapman@villanova.edu

BRUNO CORBARA

Global Canopy Programme

b.corbara@globalcanopy.org

SOUBADRA DEVY

Ashoka Trust for Research on Ecology

and Environment (ATREE)

soubadra@atree.org 
CHRISTOPHER J. FROST

Warnell School of Forest Resources and

Conservation, University of Georgia

jasmonate@gmail.com (or cfrost@uga.edu)

T. GANESH

Ashoka Trust for Research on Ecology and

Environment (ATREE)

tganesh@atree.org

LEON KAGANOVSKIY

Touro College

leonkag@gmail.com

BEVERLY E. LAW

Department of Forest Ecosystems and

Society, Oregon State University

bev.law@oregonstate.edu

MAURICE LEPONCE

Royal Belgian Institute of Natural Sciences

maurice.leponce@naturalsciences.be

SCOTT E. MILLER

National Museum of Natural History,

Smithsonian Institution

millers@si.edu

WILLIAM R. MILLER

Baker University

william.miller@bakeru.edu

ANDREW MITCHELL

Global Canopy Programme

a.mitchell@globalcanopy.org

VOJTECH NOVOTNY

University of South Bohemia

novotny@entu.cas.cz

GEORGE D. WEIBLEN

University of Minnesota

gweiblen@umn.edu

PHILIP WITTMAN

Tree Foundation

drphil@canopyquest.com 